Original Research Paper

\title{
Study of an Oscillating Sliding Mechanism
}

\author{
${ }^{1}$ Florian Ion Tiberiu Petrescu, ${ }^{2}$ Taher M. Abu-Lebdeh and ${ }^{3}$ Antonio Apicella \\ ${ }^{I}$ ARoTMM-IFToMM, Bucharest Polytechnic University, Bucharest, (CE), Romania \\ ${ }^{2}$ North Carolina A and T State Univesity, United States \\ ${ }^{3}$ Department of Architecture and Industrial Design, \\ Advanced Material Lab, Second University of Naples, 81031 Aversa (CE), Italy
}

Article history

Received: 06-05-2018

Revised: 22-05-2018

Accepted: 24-05-2018

Corresponding Author: Florian Ion Tiberiu Petrescu ARoTMM-IFToMM, Bucharest Polytechnic University, Bucharest, (CE), Romania Email: scipub02@gmail.com

\begin{abstract}
A mechanism with an oscillating slider is a mechanism quite often used in the technique. It has some advantages over other similar mechanisms being able to work with accelerations and reduced forces under the same conditions with another similar mechanism. For example, an internal combustion engine could be built more efficiently with this mechanism, resulting in a motor that would successfully replace Otto's classic one. In the paper, the kinematics, forces and their distribution will be presented within such a mechanism.
\end{abstract}

Keywords: Sliding Mechanism, Robots, Manipulators, Automation, Engines, Mechanical Transmissions, Kinematics, Forces, Dynamics, Dynamic Kinematics, Dynamic Forces

\section{Introduction}

Figure 1 shows an oscillating sliding mechanism.

A mechanism with an oscillating slider is a mechanism quite often used in the technique. It has some advantages over other similar mechanisms being able to work with accelerations and reduced forces under the same conditions with another similar mechanism. For example, an internal combustion engine could be built more efficiently with this mechanism, resulting in a motor that would successfully replace Otto's classic one.

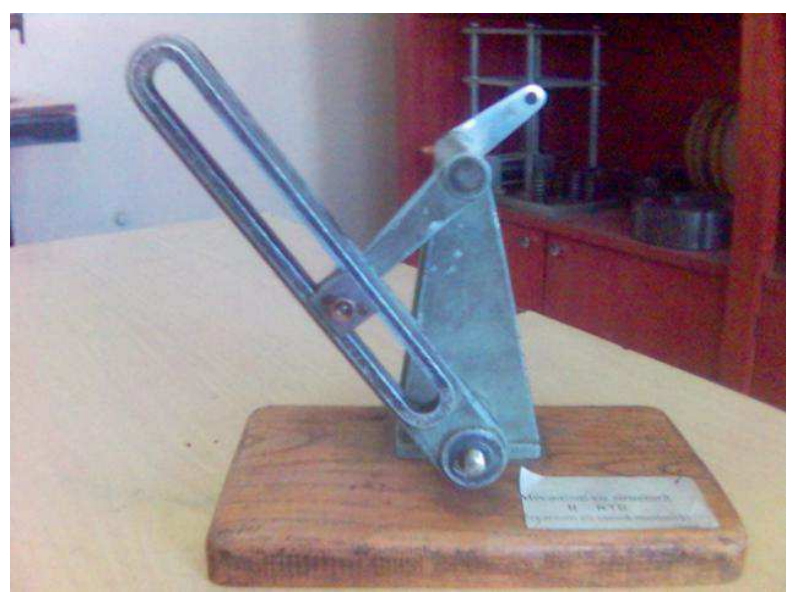

Fig. 1: An oscillating sliding mechanism
In the paper, the kinematics, forces and their distribution will be presented within such a mechanism (Frăţilă et al., 2011; Pelecudi, 1967; Antonescu, 2000; Amoresano et al., 2013; Comănescu et al., 2010; Aversa et al., 2016a; 2016b; 2016c; 2016d; 2017a; 2017b; 2017c; 2017d; 2017e; Mirsayar et al., 2017; Cao et al., 2013; Dong et al., 2013; De Melo et al., 2012; Garcia et al., 2007; GarciaMurillo et al., 2013; He et al., 2013; Lee, 2013; Lin et al., 2013; Liu et al., 2013; Padula and Perdereau, 2013; Perumaal and Jawahar, 2013; Petrescu and Petrescu, 1995a; 1995b; 1997a; 1997b; 1997c; 2000a; $2000 \mathrm{~b} ; 2002 \mathrm{a} ; 2002 \mathrm{~b}$; 2003; 2005a; 2005b; 2005c; 2005d; 2005e; 2016a; 2016b; 2016c; 2016d; 2016e; 2013; 2012a; 2012b; 2011; Petrescu et al., 2009; 2016a; 2016b; 2016c; 2016d; 2016e; 2017a; 2017b; 2017c; 2017d; 2017e; 2017f; 2017g; 2017h; 2017i; 2017j; $2017 \mathrm{k} ; 2017 \mathrm{l} ; 2017 \mathrm{~m} ; 2017 \mathrm{n} ; 2017 \mathrm{o} ; 2017 \mathrm{p} ; 2017 \mathrm{q}$; $2017 \mathrm{r} ; 2017 \mathrm{~s} ; 2017 \mathrm{t} ; 2017 \mathrm{u} ; 2017 \mathrm{v} ; 2017 \mathrm{w} ; 2017 \mathrm{x}$; 2017y; 2017z; 2017aa; 2017ab; 2017ac; 2017ad; 2017ae; Petrescu and Calautit, 2016a; 2016b; Reddy et al., 2012; Tabaković et al., 2013; Tang et al., 2013; Tong et al., 2013; Wang et al., 2013; Wen et al., 2012; Antonescu and Petrescu, 1985; 1989; Antonescu et al., 1985a; 1985b; 1986; 1987; 1988; 1994; 1997; 2000a; 2000b; 2001; List the first flights, From Wikipedia; Chen and Patton, 1999; Fernandez et al., 2005; Fonod et al., 2015; Lu et al., 2015; 2016; Murray et al., 2010; Palumbo et al., 2012; Patre and Joshi, 2011; Sevil and Dogan, 2015; Sun and Joshi, 2009; Crickmore, 1997; 
Goodall, 2003; Graham, 2002; Jenkins, 2001; Landis and Dennis, 2005; Clément, Wikipedia; Cayley, Wikipedia; Coandă-1910, Wikipedia; Gunston, 2010; Laming, 2000; Norris, 2010; Goddard, 1916; Kaufman, 1959; Oberth, 1955; Cataldo, 2006; Gruener, 2006; Sherson et al., 2006; Williams, 1995; Venkataraman, 1992; Oppenheimer and Volkoff, 1939; Michell, 1784; Droste, 1915; Finkelstein, 1958; Gorder, 2015; Hewish, 1970).

\section{Materials and Methods}

After removing the mechanism crank, the structural group dyad RTR is isolated, a known and often used a mechatronic module (Fig. 2). The coupling parameters $C$ and $B$ are known and the kinematic parameters $s$ and $\varphi_{3}$ with their derivatives must be determined, which is done by means of the calculation relations of the system (1):

$$
\left\{\begin{array}{l}
s^{2}=\left(x_{B}-x_{C}\right)^{2}+\left(y_{B}-y_{C}\right)^{2} \Rightarrow s=\sqrt{\left(x_{B}-x_{C}\right)^{2}+\left(y_{B}-y_{C}\right)^{2}} \\
\left\{\begin{array} { l } 
{ x _ { B } = x _ { C } + s \cdot \operatorname { c o s } \varphi _ { 3 } } \\
{ y _ { B } = y _ { C } + s \cdot \operatorname { s i n } \varphi _ { 3 } } \\
{ \operatorname { c o s } \varphi _ { 3 } = \frac { x _ { B } - x _ { C } } { s } } \\
{ \operatorname { s i n } \varphi _ { 3 } = \frac { y _ { B } - y _ { C } } { s } }
\end{array} \left\{\varphi_{3}=\operatorname{semn}\left(\sin \varphi_{3}\right) \cdot \cos ^{-1}\left(\cos \varphi_{3}\right)\right.\right. \\
2 \cdot s \cdot \dot{s}=2 \cdot\left(x_{B}-x_{C}\right) \cdot\left(\dot{x}_{B}-\dot{x}_{C}\right)+2 \cdot\left(y_{B}-y_{C}\right) \cdot\left(\dot{y}_{B}-\dot{y}_{C}\right) \Rightarrow \\
\dot{s}=\frac{\left(x_{B}-x_{C}\right) \cdot\left(\dot{x}_{B}-\dot{x}_{C}\right)+\left(y_{B}-y_{C}\right) \cdot\left(\dot{y}_{B}-\dot{y}_{C}\right)}{s} \\
\ddot{s}=\frac{\left(\dot{x}_{B}-\dot{x}_{C}\right)^{2} \cdot\left(\dot{y}_{B}-\dot{y}_{C}\right)^{2}-\dot{s}^{2}}{s}+\frac{\left(x_{B}-x_{C}\right) \cdot\left(\ddot{x}_{B}-\ddot{x}_{C}\right)+\left(y_{B}-y_{C}\right) \cdot\left(\ddot{y}_{B}-\ddot{y}_{C}\right)}{s} \\
\left\{\begin{array}{l}
\dot{x}_{B}-\dot{x}_{C}=\dot{s} \cdot \cos \varphi_{3}-s \cdot \sin \varphi_{3} \cdot \dot{\varphi}_{3} \mid \cdot\left(-\sin \varphi_{3}\right) \\
\dot{y}_{B}-\dot{y}_{C}=\dot{s} \cdot \sin \varphi_{3}+s \cdot \cos \varphi_{3} \cdot \dot{\varphi}_{3} \mid \cdot\left(\cos \varphi_{3}\right)
\end{array} \Rightarrow \dot{\varphi}_{3}=\frac{\left(\dot{y}_{B}-\dot{y}_{C}\right) \cos \varphi_{3}-\left(\dot{x}_{B}-\dot{x}_{C}\right) \cdot \sin \varphi_{3}}{s}\right. \\
\left(\begin{array}{l}
\ddot{x}_{B}-\ddot{x}_{C}=\ddot{s} \cdot \cos \varphi_{3}-2 \cdot \dot{s} \cdot \sin \varphi_{3} \cdot \dot{\varphi}_{3} \\
-s \cdot \cos \varphi_{3} \cdot \dot{\varphi}_{3}^{2}-s \cdot \sin \varphi_{3} \cdot \ddot{\varphi}_{3} \mid \cdot\left(-\sin \varphi_{3}\right) \\
\ddot{y}_{B}-\ddot{y}_{C}=\ddot{s} \cdot \sin \varphi_{3}-2 \cdot \dot{s} \cdot \cos \varphi_{3} \cdot \dot{\varphi}_{3} \\
-s \cdot \sin \varphi_{3} \cdot \dot{\varphi}_{3}^{2}+s \cdot \cos \varphi_{3} \cdot \ddot{\varphi}_{3} \mid \cdot\left(\cos \varphi_{3}\right)
\end{array}\right.
\end{array}\right.
$$

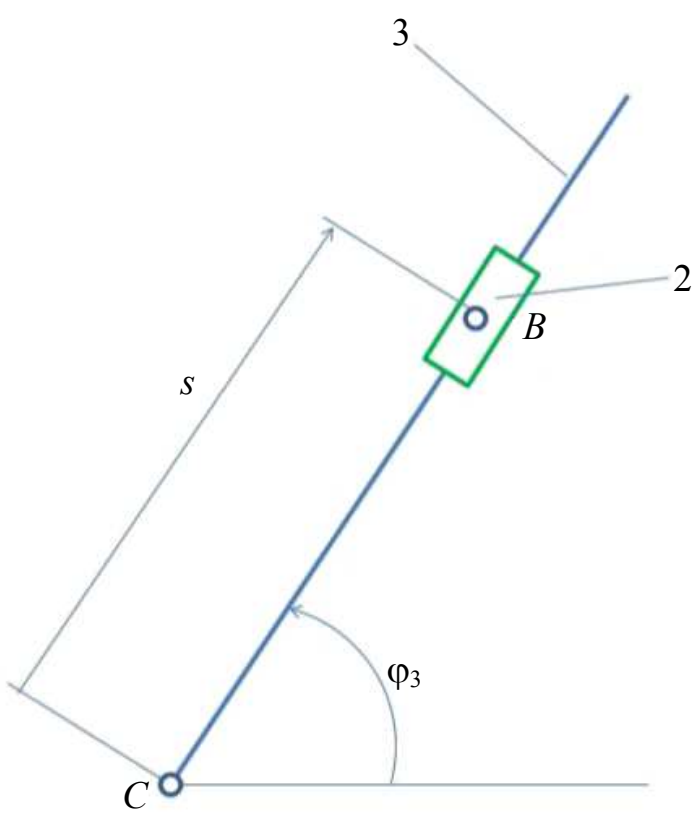

Fig. 2: The structural group, a dyad RTR 
The forces from the dyad of the third RTR aspect can be traced in Fig. 3 and the calculations in the relational system (2):

$$
\begin{aligned}
& \left\{\begin{array} { l } 
{ x _ { G _ { 3 } } = x _ { C } + s _ { 3 } \cdot \operatorname { c o s } \varphi _ { 3 } } \\
{ y _ { G _ { 3 } } = y _ { C } + s _ { 3 } \cdot \operatorname { s i n } \varphi _ { 3 } }
\end{array} \left\{\begin{array}{l}
\dot{x}_{G_{3}}=\dot{x}_{C}-s_{3} \cdot \sin \varphi_{3} \cdot \dot{\varphi}_{3} \\
\dot{y}_{G_{3}}=\dot{y}_{C}+s_{3} \cdot \cos \varphi_{3} \cdot \dot{\varphi}_{3}
\end{array}\right.\right. \\
& \Rightarrow\left\{\begin{array}{l}
\ddot{x}_{G_{3}}=\ddot{x}_{C}-s_{3} \cdot \cos \varphi_{3} \cdot \dot{\varphi}_{3}^{2}-s_{3} \sin \varphi_{3} \cdot \ddot{\varphi}_{3} \\
\ddot{y}_{G_{3}}=\ddot{y}_{C}-s_{3} \cdot \sin \varphi_{3} \cdot \dot{\varphi}_{3}^{2}+s_{3} \cos \varphi_{3} \cdot \ddot{\varphi}_{3}
\end{array}\right. \\
& \int F_{G_{3}}^{i x}=-m_{3} \cdot \ddot{x}_{G_{3}}\left(F_{G_{2}}^{i x}=-m_{2} \cdot \ddot{x}_{G_{3}}=-m_{2} \cdot \ddot{x}_{B}\right. \\
& \left\{F_{G_{3}}^{i v}=-m_{3} \cdot \ddot{y}_{G_{3}}\left\{F_{G_{2}}^{i v}=-m_{2} \cdot \ddot{y}_{G_{2}}=-m_{2} \cdot \ddot{y}_{B}\right.\right. \\
& M_{3}^{i}=-J_{G_{3}} \cdot \ddot{\varphi}_{3} \quad M_{2}^{i}=-J_{G_{2}} \cdot \ddot{\varphi}_{2}=-J_{G_{2}} \cdot \ddot{\varphi}_{3} \\
& \sum M_{B}^{(2)}=0 \Rightarrow M_{32}+M_{2}^{i}=0 \Rightarrow M_{32}=-M_{2}^{i} \Rightarrow M_{23}=M_{2}^{i} \\
& \sum M_{C}^{(3)}=0 \Rightarrow R_{23} \cdot s+M_{23}+M_{3}^{i}-F_{G_{3}}^{i x} \cdot\left(y_{G_{3}}-y_{C}\right) \\
& +F_{G_{3}}^{i \nu} \cdot\left(x_{G_{3}}-x_{C}\right)=0 \\
& \left\{R_{23}=\frac{F_{G_{3}}^{i x} \cdot\left(y_{G_{3}}-y_{C}\right)+F_{G_{3}}^{i y} \cdot\left(x_{C}-x_{G_{3}}\right)-M_{23}=M_{3}^{i}}{s}\right. \\
& R_{32}=-R_{23} \Rightarrow\left\{\begin{array}{l}
R_{32}^{x}=R_{32} \cdot \cos \left(\varphi_{3}+\frac{\pi}{2}\right)=-R_{32} \cdot \sin \varphi_{3} \\
R_{32}^{y}=R_{32} \cdot \sin \left(\varphi_{3}+\frac{\pi}{2}\right)=R_{32} \cdot \cos \varphi_{3}
\end{array}\right. \\
& \sum F_{x}^{(2)}=0 \Rightarrow R_{12}^{x}+R_{32}^{x}+F_{G_{2}}^{i x}=0 \Rightarrow R_{12}^{x}=-R_{32}^{x}-F_{G_{2}}^{i x} \\
& \sum F_{y}^{(2)}=0 \Rightarrow R_{12}^{y}+R_{32}^{y}+F_{G_{2}}^{i y}=0 \Rightarrow R_{12}^{y}=-R_{32}^{y}-F_{G_{2}}^{i y} \\
& \Rightarrow R_{12}=\sqrt{\left(R_{12}^{x}\right)^{2}+\left(R_{12}^{y}\right)^{2}} \\
& \sum F_{x}^{(3)}=0 \Rightarrow R_{03}^{x}+F_{G_{3}}^{i x}+R_{23}^{x}=0 \Rightarrow R_{03}^{x}=-F_{G_{3}}^{i x}+R_{32}^{x} \\
& \sum F_{y}^{(3)}=0 \Rightarrow R_{03}^{y}+F_{G_{3}}^{i y}+R_{23}^{y}=0 \Rightarrow R_{03}^{y}=-F_{G_{3}}^{i y}+R_{32}^{y} \\
& \Rightarrow R_{03}=\sqrt{\left(R_{03}^{x}\right)^{2}+\left(R_{03}^{y}\right)^{2}}
\end{aligned}
$$

The distribution of forces to the mechanism having an oscillating slide is made for the compressor mode according to Fig. 4. The calculation relations are given by the system (3). Force distribution shows how the forces are distributed within the module elements and takes into account the kinematic couplers existing within the module. It is totally different from the forces in that mechanism that show the forces that load the module onto the elements and the couplings. Forces distribution also shows how forces are transmitted from one element to the next element of the module within the link couple between the two mobile elements:

$$
\begin{aligned}
& \cos \gamma=\cos \left(\frac{3 \pi}{2}+\varphi_{3}-\varphi_{1}\right)=\cos \left(\varphi_{1}-\varphi_{3}-\frac{3 \pi}{2}\right) \\
& =\sin \left(2 \pi-\varphi_{1}-\varphi_{3}\right)=\sin \left(\varphi_{3}-\varphi_{1}\right) \\
& F_{u}=F_{m} \cdot \cos \gamma F_{m} \cdot \sin \left(\varphi_{3}-\varphi_{1}\right) \\
& v_{m}=v_{B}=l_{1} \cdot \omega_{1} \\
& v_{u} \equiv \dot{s}=v_{m} \cdot \sin \left(\varphi_{3}-\varphi_{1}\right) \\
& \Rightarrow \eta_{i}^{c}=\frac{F_{u} \cdot \dot{s}}{F_{m} \cdot v_{m}} \\
& \left\{\Rightarrow \eta_{i}^{c}=\frac{F_{m} \cdot \sin \left(\varphi_{3}-\varphi_{1}\right) \cdot v_{m} \cdot \sin \left(\varphi_{3}-\varphi_{1}\right)}{F_{m} \cdot v_{m}}=\sin ^{2}\left(\varphi_{3}-\varphi_{1}\right)\right. \\
& \eta_{i}^{D C}=\frac{F_{u} \cdot \dot{s}}{F_{m} \cdot v_{m}}=\frac{F_{m} \sin \left(\varphi_{3}-\varphi_{1}\right) v_{m} \sin \left(\varphi_{3}-\varphi_{1}\right)}{F_{m} \cdot v_{m}}=\sin ^{2}\left(\varphi_{3}-\varphi_{1}\right) \\
& \Rightarrow\left\{\begin{array}{l}
\eta_{i}^{D c}=\eta_{i}^{c} \\
\eta_{i}^{D c}=D^{c} \cdot \eta_{i}^{c}
\end{array} \Rightarrow D^{c}=1\right. \\
& \eta_{i}^{c} \sin ^{2}\left(\varphi_{3}-\varphi_{1}\right) \\
& \Rightarrow \eta_{i}^{c}=\frac{l_{0}^{2} \cdot \cos ^{2} \varphi_{1}}{l_{0}^{2}+l_{1}^{2}+2 \cdot l_{0} \cdot l_{1} \cdot \sin \varphi_{1}}=\frac{\cos ^{2} \varphi_{1}}{1+\lambda^{2}+2 \cdot \lambda \cdot \sin \varphi_{1}} \lambda=\frac{l_{1}}{l_{0}}
\end{aligned}
$$

For the motor regime, the force distribution can be traced in Fig. 5 and the corresponding calculation relationships are given by the relational system (4).

Here, it should be made clear that the two mechanisms of the mechanism considered as a motor mechanism are appropriate to the two separate phases. When the mechanism is operated from the crank we have a compressor regime in which the engine mechanism works.

When actuating from the piston, the mechanism actually switches to the engine, which is the only one that gives power to the engine directly. And in the compressor mode, power is transmitted to the mechanism either due to inertial forces or due to the action of other engine regimes from other cylinders in work, knowing that an internal combustion engine generally has more cylinders and not just one:

$$
\begin{aligned}
& \int \cos \gamma=\cos \left(\frac{3 \pi}{2}+\varphi_{3}-\varphi_{1}\right)=\cos \left(\varphi_{1}-\varphi_{3}-\frac{3 \pi}{2}\right) \\
& =\sin \left(2 \pi-\varphi_{1}-\varphi_{3}\right)=\sin \left(\varphi_{3}-\varphi_{1}\right) \\
& F_{u}=F_{m} \cdot \cos \gamma=F_{m} \cdot \sin \left(\varphi_{3}-\varphi_{1}\right) \\
& \left\{v_{u}=v_{B}=l_{1} \cdot \omega_{1} v_{u}^{D}=v_{m} \cdot \sin \left(\varphi_{3}-\varphi_{1}\right)\right. \\
& v_{m} \equiv \dot{s}=v_{B} \cdot \sin \left(\varphi_{3}-\varphi_{1}\right) \\
& \Rightarrow \eta_{i}^{M}=\frac{F_{u} \cdot v_{u}}{F_{m} \cdot \dot{s}}=\frac{F_{m} \cdot \sin \left(\varphi_{3}-\varphi_{1}\right) \cdot v_{B}}{F_{m} \cdot v_{B} \cdot \sin \left(\varphi_{3}-\varphi_{1}\right)}=1 \\
& \eta_{i}^{D M}=\frac{F_{u} \cdot v_{u}^{D}}{F_{m} \cdot v_{m}}=\frac{F_{m} \sin \left(\varphi_{3}-\varphi_{1}\right) v_{m} \sin \left(\varphi_{3}-\varphi_{1}\right)}{F_{m} \cdot v_{m}}=\sin ^{2}\left(\varphi_{3}-\varphi_{1}\right) \\
& \Rightarrow\left\{\begin{array}{l}
\eta_{i}^{D M}=\sin ^{2}\left(\varphi_{3}-\varphi_{1}\right) \\
\eta_{i}^{D M}=D^{M} \cdot \eta_{i}^{M}=D^{M}
\end{array} \Rightarrow D^{M} \sin ^{2}\left(\varphi_{3}-\varphi_{1}\right) ; \eta_{i}^{M}=1\right.
\end{aligned}
$$




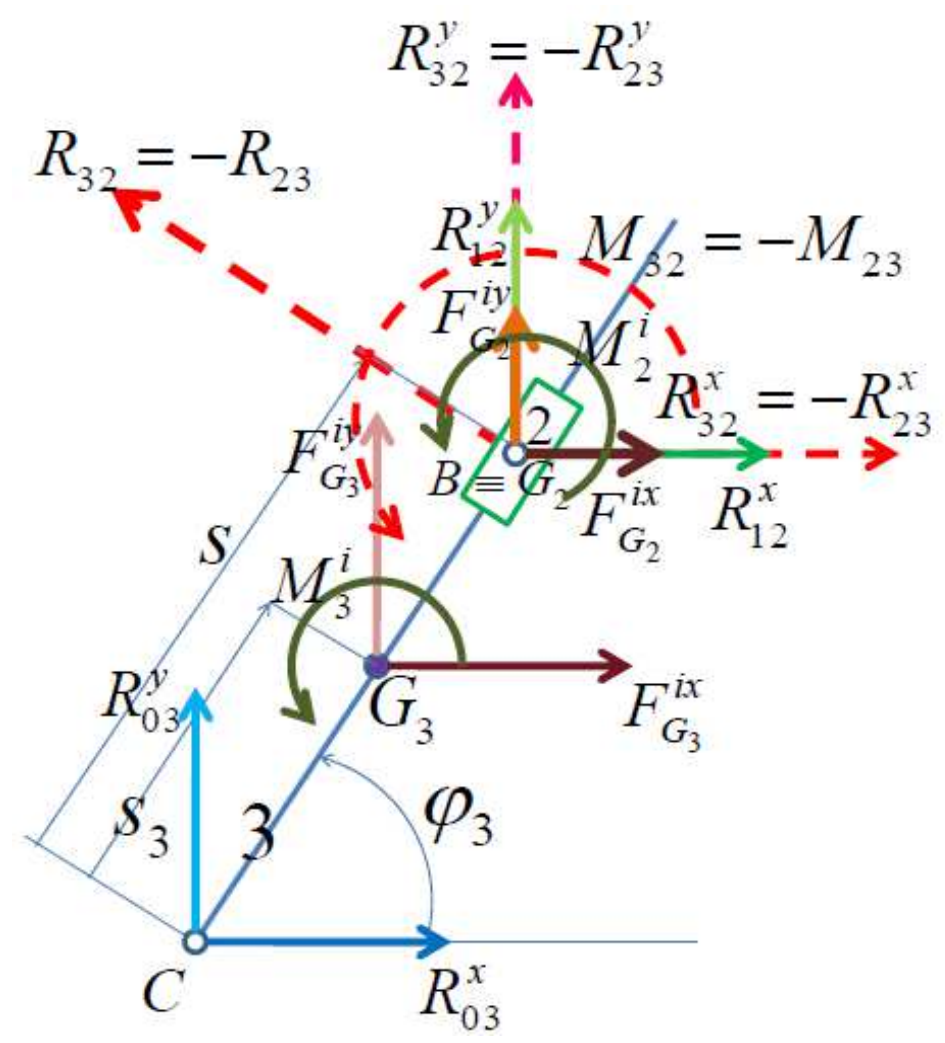

Fig. 3: The forces from the structural group, the dyad RTR

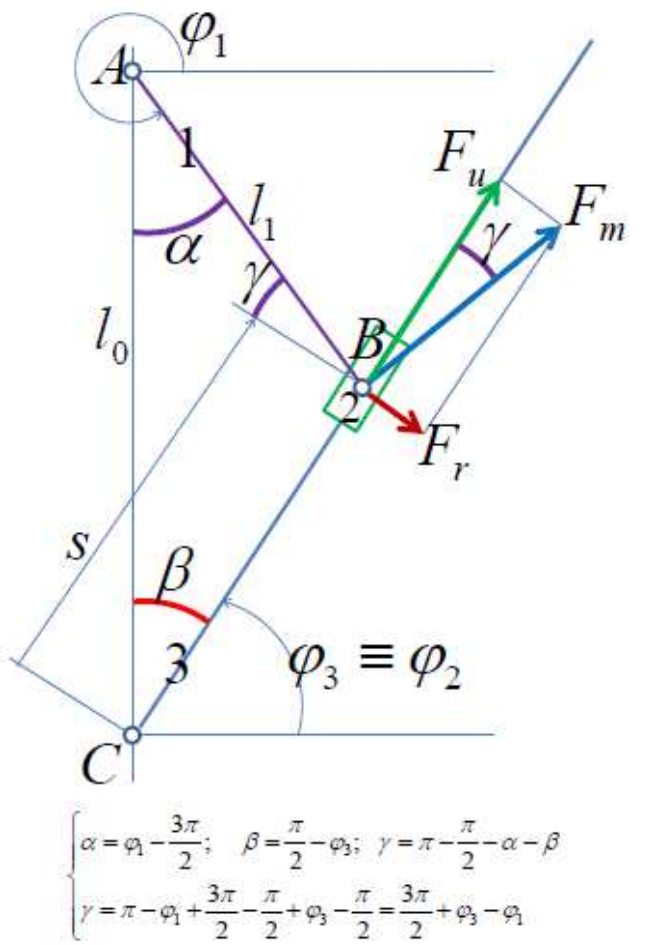

Fig. 4: The distribution of forces to the mechanism having an oscillating slide, in a compresor regime

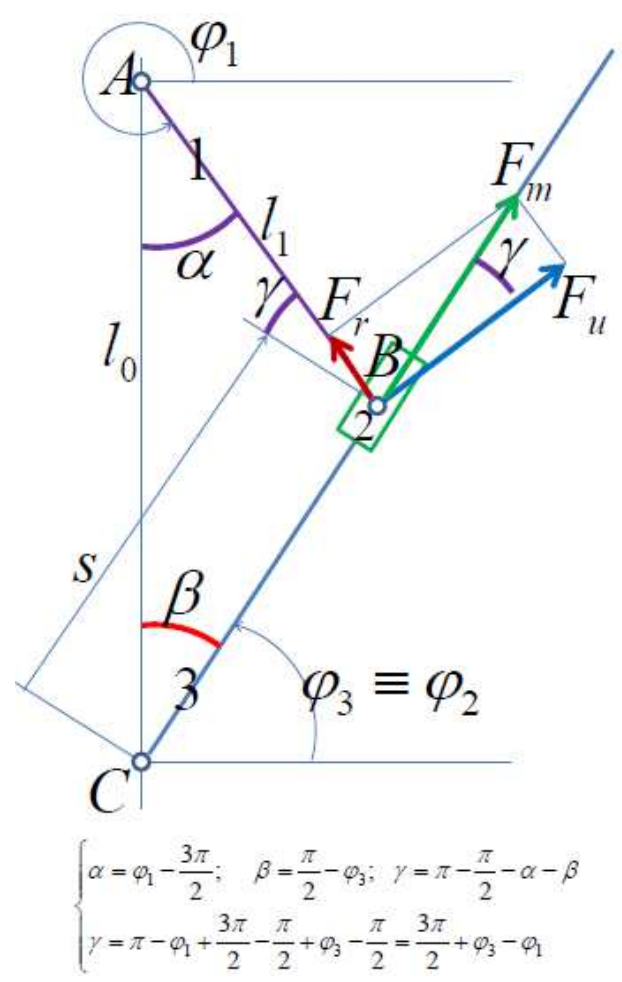

Fig. 5: The distribution of forces to the mechanism having an oscillating slide, working in a engine regime 


\section{Results and Discussion}

The dynamic calculation requires the determination of the variable angular velocity of the steering crank 1 and the corresponding angular acceleration. The angular velocity is determined with known relationships (5):

$$
\left\{\begin{array}{l}
\omega^{D}=D \cdot \omega \\
D^{C}=1 \\
D^{M}=\sin ^{2}\left(\varphi_{3}-\varphi_{1}\right)=\frac{l_{0}^{2} \cdot \cos ^{2} \varphi_{1}}{l_{0}^{2}+l_{1}^{2}+2 \cdot l_{0} \cdot l_{1} \cdot \sin \varphi_{1}} \\
\omega^{D C}=D^{C} \cdot \omega=\omega ; \omega^{D M}=D^{M} \cdot \omega=\sin ^{2}\left(\varphi_{3}-\varphi_{1}\right) \cdot \omega
\end{array}\right.
$$

Angular acceleration is calculated with relations (6):

$$
\left\{\begin{array}{l}
D^{C}=1 \Rightarrow \varepsilon^{C}=0 \\
D^{M}=\sin ^{2}\left(\varphi_{3}-\varphi_{1}\right)=\frac{l_{0}^{2} \cdot \cos ^{2} \varphi_{1}}{l_{0}^{2}+l_{1}^{2}+2 \cdot l_{0} \cdot l_{1} \cdot \sin \varphi_{1}} \\
\Rightarrow \varepsilon^{M} \equiv \varepsilon_{1}=\left(\dot{\omega}^{D M}\right)=\frac{d\left(D^{M} \cdot \omega\right)}{d t}=D^{M^{\prime}} \cdot \omega^{2} \\
D^{M^{\prime}}=\sin \left[2 \cdot\left(\varphi_{3}-\varphi_{1}\right)\right] \cdot\left(\varphi_{3}^{\prime}-1\right) \\
D^{M^{\prime}}=\sin \left[2 \cdot\left(\varphi_{3}-\varphi_{1}\right)\right] \cdot \frac{l_{1} \cdot \cos \left(\varphi_{3}-\varphi_{1}\right)-s}{s} \\
\varepsilon^{M}=\sin \left[2 \cdot\left(\varphi_{3}-\varphi_{1}\right)\right] \cdot \frac{l_{1} \cdot \cos \left(\varphi_{3}-\varphi_{1}\right)-s}{s} \cdot \omega^{2}
\end{array}\right.
$$

The moment of mechanical or mass inertia (of the whole mechanism) reduced to the crank is determined by the relation (7):

$$
\begin{aligned}
& J^{*}=J_{G_{1}}+\left(J_{G_{2}}+J_{G_{3}}\right) \cdot\left(\frac{\omega_{3}}{\omega_{1}}\right)^{2} \\
& +m_{2} \cdot\left(x_{G_{2}}^{\prime 2}+y_{G_{2}}^{\prime 2}\right)+m_{3} \cdot\left(x_{G_{3}}^{\prime 2}+y_{G_{3}}^{\prime 2}\right) \Rightarrow \\
& J^{*}=J_{G_{1}}+\left(J_{G_{2}}+J_{G_{3}}\right) \cdot\left(\frac{\omega_{3}}{\omega_{1}}\right)^{2} \\
& +m_{2} \cdot\left(x_{B}^{\prime 2}+y_{B}^{\prime 2}\right)+m_{3} \cdot\left(x_{G_{3}}^{\prime 2}+y_{G_{3}}^{\prime 2}\right)
\end{aligned}
$$

The positioning of the weight centers of the mechanism is made according to the kinematic scheme shown in Fig. 6 so that the center of gravity of the movable element 2 coincides with the joint $\mathrm{B}$ and the center of gravity of the element 1 (already balanced) coincides with the fixed joint A.

Such a mechanism used as a motor mechanism can bring great advantages due to its better functioning, with much smaller accelerations and shocks compared to the classic Otto engines, thus achieving a smooth operation without shocks and vibrations so virtually no noise or interruptions, lower smoke, low fuel consumption at a higher installed power, with a superior dynamics even with classic Otto engines.

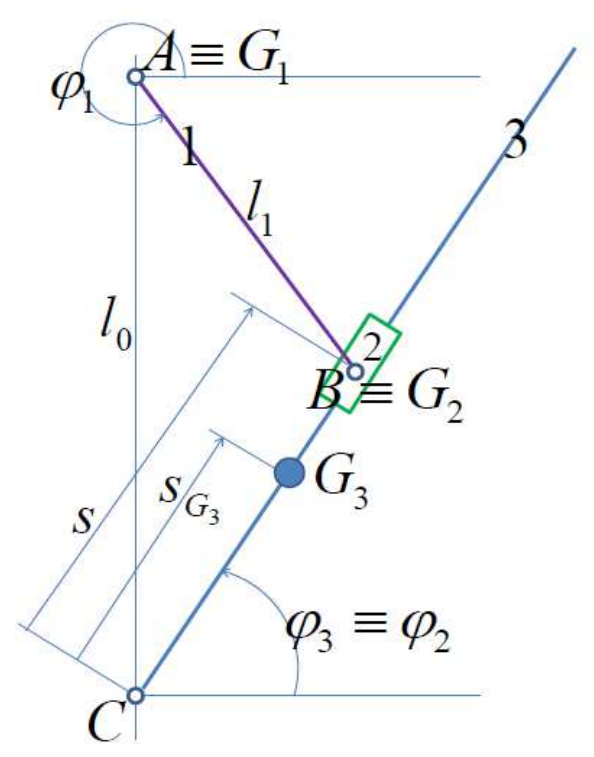

Fig. 6: The weight centers of the swing slide mechanism

The big advantages of such an engine are today translated by their possible use of gasoline and gas, to the detriment of diesel and diesel engines, as we can extend the life of gasoline engines for about 200 years and those for gas for at least 1000 years, given that we will have enough gas for stoves in the kitchens of the housewives or restaurants, but by clearly eliminating the consumption of gas to obtain electric or thermal energy, which are quickly replaced by nuclear power plants and regenerative energies, headed by the sun and the wind.

\section{Conclusion}

A mechanism with an oscillating slider is a mechanism quite often used in the technique. It has some advantages over other similar mechanisms being able to work with accelerations and reduced forces under the same conditions with another similar mechanism.

For example, an internal combustion engine could be built more efficiently with this mechanism, resulting in a motor that would successfully replace Otto's classic one. In the paper, the kinematics, forces and their distribution will be presented within such a mechanism.

To the presented motor mechanism the dynamickinematics is different from the classical-kinematics known, but when the constructive parameters are setting on normal values, the dynamic motor velocities and accelerations take the same values as the classical motor speeds and accelerations known.

In the presented article was showed a new model of an internal combustion engine, able to running with reduced exhaust emissions.

The new mechanism was designed and intended for industrial production. 
As long as we produce electricity and heat by burning fossil fuels is pointless to try to replace all thermal engines with electric motors, as loss of energy and pollution will be even larger. However, it is well to continuously improve the thermal engines, to reduce thus fuel consumption.

\section{Acknowledgement}

This text was acknowledged and appreciated by Dr. Veturia CHIROIU Honorific member of Technical Sciences Academy of Romania (ASTR) PhD supervisor in Mechanical Engineering.

\section{Funding Information}

Research contract: Contract number 36-5-4D/1986 from 24IV1985, beneficiary CNST RO (Romanian National Center for Science and Technology) Improving dynamic mechanisms internal combustion engines. All these matters are copyrighted. Copyrights: 548cgiywDssin, from: 22-04-2010, 08:48:48.

\section{Author's Contributions}

All the authors contributed equally to prepare, develop and carry out this manuscript.

\section{Ethics}

This article is original and contains unpublished material. Authors declare that are not ethical issues and no conflict of interest that may arise after the publication of this manuscript.

\section{References}

Amoresano, A., V. Avagliano, V. Niola and G. Quaremba, 2013. The assessment of the in-cylinder Pressure by means of the morpho-dynamical vibration analysis-methodology and application. IREME J., 7: 999-1006.

Antonescu, P., 2000. Mechanisms and Handlers, Printech Publishing House. Bucharest.

Antonescu, P. and F. Petrescu, 1985. Analytical method of synthesis of cam mechanism and flat stick. Proceedings of the 4th International Symposium on Mechanism Theory and Practice, (TPM' 85), Bucharest.

Antonescu, P. and F. Petrescu, 1989. Contributions to cinetoelastodynamic analysis of distribution mechanisms. Bucharest.

Antonescu, P., M. Oprean and F. Petrescu, 1985a. Contributions to the synthesis of oscillating cam mechanism and oscillating flat stick. Proceedings of the 4th International Symposium on Theory and Practice of Mechanisms, (TPM' 85), Bucharest.
Antonescu, P., M. Oprean and F. Petrescu, 1985b. At the projection of the oscillante cams, there are mechanisms and distribution variables. Proceedings of the V-Conference for Engines, Automobiles, Tractors and Agricultural Machines, I-Engines and Automobiles, (AMA’ 85), Brasov.

Antonescu, P., M. Oprean and F. Petrescu, 1986. Projection of the profile of the rotating camshaft acting on the oscillating plate with disengagement. Proceedings of the 3rd National Computer Assisted Designing Symposium in Mechanisms and Machine Bodies, (MOM' 86), Brasov.

Antonescu, P., M. Oprean and F. Petrescu, 1987. Dynamic analysis of the cam distribution mechanisms. Proceedings of the 7 th National Symposium of Industrial Robots and Spatial Mechanisms, (IMS' 87), Bucharest.

Antonescu, P., M. Oprean and F. Petrescu, 1988. Analytical synthesis of Kurz profile, rotating flat cam. Machine Build. Rev. Bucharest.

Antonescu, P., F. Petrescu and O. Antonescu, 1994. Contributions to the synthesis of the rotating cam mechanism and the tip of the balancing tip. Brasov.

Antonescu, P., F. Petrescu and D. Antonescu, 1997. Geometrical synthesis of the rotary cam and balance tappet mechanism. Bucharest.

Antonescu, P., F. Petrescu and O. Antonescu, 2000a. Contributions to the synthesis of the rotary disc-cam profile. Proceedings of the 8th International Conference on Theory of Machines and Mechanisms, (TMM' 00), Liberec, Czech Republic, pp: 51-56.

Antonescu, P., F. Petrescu and O. Antonescu, 2000b. Synthesis of the rotary cam profile with balance follower. Proceedings of the 8th Symposium on Mechanisms and Mechanical Transmissions, (MMT'000), Timişoara, pp: 39-44.

Antonescu, P., F. Petrescu and O. Antonescu, 2001. Contributions to the synthesis of mechanisms with rotary disc-cam. Proceedings of the 8th IFToMM International Symposium on Theory of Machines and Mechanisms, (TMM' 01), Bucharest, ROMANIA, pp: 31-36.

Aversa, R., R.V. Petrescu, A. Apicella and F.I.T. Petrescu, 2017a. Nano-diamond hybrid materials for structural biomedical application. Am. J. Biochem. Biotechnol., 13: 34-41. DOI: 10.3844 /ajbbsp.2017.34.41

Aversa, R., R.V. Petrescu, B. Akash, R.B. Bucinell and J.M. Corchado et al., 2017b. Kinematics and forces to a new model forging manipulator. Am. J. Applied Sci., 14: 60-80. DOI: 10.3844/ajassp.2017.60.80

Aversa, R., R.V. Petrescu, A. Apicella, F.I.T. Petrescu and J.K. Calautit et al., 2017c. Something about the $\mathrm{V}$ engines design. Am. J. Applied Sci., 14: 34-52. DOI: 10.3844 /ajassp.2017.34.52 
Aversa, R., D. Parcesepe, R.V. Petrescu, F. Berto and G. Chen et al., 2017d. Processability of bulk metallic glasses. Am. J. Applied Sci., 14: 294-301. DOI: 10.3844/ajassp.2017.294.301

Aversa, R., R.V. Petrescu, A. Apicella and F.I.T. Petrescu, 2017e. Modern transportation and photovoltaic energy for urban ecotourism. Transylvanian Rev. Administrative Sci., 13: 5-20. DOI: $10.24193 /$ tras.SI2017.1

Aversa, R., F.I.T. Petrescu, R.V. Petrescu and A. Apicella, 2016a. Biomimetic FEA bone modeling for customized hybrid biological prostheses development. Am. J. Applied Sci., 13: 1060-1067. DOI: 10.3844/ajassp.2016.1060.1067

Aversa, R., D. Parcesepe, R.V. Petrescu, G. Chen and F.I.T. Petrescu et al., 2016b. Glassy amorphous metal injection molded induced morphological defects. Am. J. Applied Sci., 13: 1476-1482.

DOI: 10.3844/ajassp.2016.1476.1482

Aversa, R., R.V. Petrescu, F.I.T. Petrescu and A. Apicella, 2016c. Smart-factory: Optimization and process control of composite centrifuged pipes. Am. J. Applied Sci., 13: 1330-1341.

DOI: 10.3844/ajassp.2016.1330.1341

Aversa, R., F. Tamburrino, R.V. Petrescu, F.I.T. Petrescu and M. Artur et al., 2016d. Biomechanically inspired shape memory effect machines driven by muscle like acting NiTi alloys. Am. J. Applied Sci., 13: 1264-1271. DOI: 10.3844/ajassp.2016.1264.1271

Cao, W., H. Ding, Z. Bin and C. Ziming, 2013. New structural representation and digital-analysis platform for symmetrical parallel mechanisms. Int. J. Adv. Robot. Sys. DOI: 10.5772/56380

Cataldo, R., 2006. Overview of planetary power system options for education. ITEA Human Exploration Project Authors, 2006, at Glenn Research Center. Brooke Park, $\mathrm{OH}$.

Cayley George, From Wikipedia. The free encyclopedia. https://en.wikipedia.org/wiki/George_Cayley

Chen, J. and R.J. Patton, 1999. Robust Model-Based Fault Diagnosis for Dynamic Systems. 1st Edn., Kluwer Academic Publisher, Boston.

Clément, A., From Wikipedia. The free encyclopedia. https://en.wikipedia.org/wiki/Cl\%C3\%A9ment_A der

Coandă-1910, From Wikipedia. The free encyclopedia. https://en.wikipedia.org/wiki/Coand\%C4\%83-1910

Comănescu, A., D. Comănescu, I. Dugăeşescu and A. Boureci, 2010. The Basics of Modeling Mechanisms. 1st Edn., Politehnica Press Publishing House, Bucharest, ISBN-10: 978-606-515-115-4, pp: 274.

Crickmore, P.F., 1997. Lockheed's blackbirds-A-12, YF12 and SR-71A. Wings Fame, 8: 30-93.
Dong, H., N. Giakoumidis, N. Figueroa and N. Mavridis, 2013. Approaching behaviour monitor and vibration indication in developing a General Moving Object Alarm System (GMOAS). Int. J. Adv. Robot. Sys. DOI: 10.5772/56586

Droste, J., 1915. On the field of a single centre in Einstein's theory of gravitation. Koninklijke Nederlandsche Akademie van Wetenschappen Proc., 17: 998-1011.

De Melo, L.F., R.A., S.F. Rosário and J.M., Rosário, 2012. Mobile robot navigation modelling, control and applications. Int. Rev. Modell. Simulations, 5: 1059-1068.

Fernandez, V., F. Luis, L.F. Penin, J. Araujo and A. Caramagno, 2005. Modeling and FDI specification of a RLV Re-entry for robust estimation of sensor and actuator faults. Proceedings of the AIAA Guidance, Navigation and Control Conference and Exhibit, Aug. 15-18, San Francisco.

DOI: $10.2514 / 6.2005-6254$

Finkelstein, D., 1958. Past-future asymmetry of the gravitational field of a point particle. Physical Rev., 110: 965-967.

Fonod, R., D. Henry, C. Charbonnel and E. Bornschlegl, 2015. Position and attitude model-based thruster fault diagnosis: A comparison study. J. Guidance Control Dynam., 38: 1012-1026. DOI: $10.2514 / 1 . G 000309$

Frăţilă, G., M. Frăţilă and S. Samoilă, 2011. Automobiles, Construction, Exploitation, Reparation. 10th Edn., EDP, Bucharest, ISBN-10: 978-973-30-2857-4.

Garcia, E., M.A. Jimenez, P.G. De Santos and M. Armada, 2007. The evolution of robotics research. IEEE Robot. Autom. Magaz., 14: 90-103. DOI: 10.1109/MRA.2007.339608

Garcia-Murillo, M., J. Gallardo-Alvarado and E. Castillo-Castaneda, 2013. Finding the generalized forces of a series-parallel manipulator. IJARS. DOI: $10.5772 / 53824$

Goddard, 1916. Rocket apparatus patent December 15, 1916, Smithsonian Institution Archives.

Goodall, J., 2003. Lockheed's SR-71 "Blackbird" Family. Hinckley, UK: Aerofax/Midland Publishing, 2003. (ISBN 1-85780-138-5).

Gorder, P.F., 2015. What's on the surface of a black hole? Not a "firewall"- and the nature of the universe depends on it, a physicist explains.

Graham, R.H., 2002. SR-71 Blackbird: Stories, Tales and Legends. 1st Edn., Zenith Imprint, North Branch, Minnesota, ISBN-10: 1610607503.

Gruener, J.E., 2006. Lunar exploration (Presentation to ITEA Human Exploration Project Authors, November 2006, at Johnson Space Center). Houston, TX. 
Gunston, B., 2010. Airbus: The Complete Story. 1st Edn., Haynes Publishing UK, Sparkford, ISBN-10: 1844255859, pp: 288.

He, B., Z. Wang, Q. Li, H. Xie and R. Shen, 2013. An analytic method for the kinematics and dynamics of a multiple-backbone continuum robot. IJARS. DOI: $10.5772 / 54051$

Hewish, A., 1970. Pulsars. Ann. Rev. Astronomy Astrophysics, 8: 265-296.

Jenkins, D.R., 2001. Lockheed Secret Projects: Inside the Skunk Works. 1st Edn., Zenith Imprint, St. Paul, Minnesota: MBI Publishing Company, ISBN-10: 1610607287.

Kaufman, H.R., 1959. Installations at NASA Glenn.

Laming, T., 2000. Airbus A320. 1st Edn., Zenith Press.

Landis, T.R. and D.R. Jenkins, 2005. Lockheed Blackbirds. 1st Edn., Specialty Press, North Branch, ISBN-10: 1580070868, pp: 104.

Lee, B.J., 2013. Geometrical derivation of differential kinematics to calibrate model parameters of flexible manipulator. Int. J. Adv. Robot. Syst. DOI: $10.5772 / 55592$

Lin, W., B. Li, X. Yang and D. Zhang, 2013. Modelling and control of inverse dynamics for a 5-DOF parallel kinematic polishing machine. Int. J. Adv. Robot. Sys. DOI: 10.5772/54966

List the first flights, From Wikipedia, free encyclopedia.

Liu, H., W. Zhou, X. Lai and S. Zhu, 2013. An efficient inverse kinematic algorithm for a PUMA560structured robot manipulator. IJARS. DOI: $10.5772 / 56403$

Lu, P., L. Van Eykeren, E.J. Van Kampen and Q.P. Chu, 2015. Selective-reinitialization multiple-model adaptive estimation for fault detection and diagnosis. J. Guidance Control Dynam., 38: 1409-1424. DOI: 10.2514/1.G000587

Lu, P., L. Van Eykeren, E. van Kampen, C. C. de Visser and Q.P. Chu, 2016. Adaptive three-step kalman filter for air data sensor fault detection and diagnosis. J. Guidance Control Dynam., 39: 590-604. DOI: 10.2514/1.G001313

Michell, J., 1784. On the means of discovering the distance, magnitude and c. of the fixed stars, in consequence of the diminution of the velocity of their light, in case such a diminution should be found to take place in any of them and such other data should be procured from observations, as would be farther necessary for that purpose. Philosophical Trans. Royal Society, 74: 35-57. DOI: 10.1098/rstl.1784.0008

Mirsayar, M.M., V.A. Joneidi, R.V. Petrescu, F.I.T. Petrescu and F. Berto, 2017. Extended MTSN criterion for fracture analysis of soda lime glass. Eng. Fracture Mechan., 178: 50-59.

DOI: $10.1016 /$ j.engfracmech.2017.04.018
Murray, K., A. Marcos and L.F. Penin, 2010. Development and testing of a GNC-FDI filter for a reusable launch vehicle during ascent. Proceedings of the AIAA Guidance, Navigation and Control Conference, Aug. 2-5, Toronto, Ontario Canada. DOI: $10.2514 / 6.2010-8195$

Norris, G., 2010. Airbus A380: Superjumbo of the 21st Century. 1st Edn., Zenith Press.

Oberth, H., 1955. They come from outer space. Flying Saucer Rev., 1: 12-14.

Oppenheimer, J.R. and G.M. Volkoff, 1939. On massive neutron cores. Physical Rev., 55: 374-381.

Padula, F. and V. Perdereau, 2013. An on-line path planner for industrial manipulators. Int. J. Adv. Robot. Syst. DOI: 10.5772/55063

Palumbo, R., G. Morani, M. De Stefano Fumo, C. Richiello and M. Di Donato et al., 2012. Concept study of an atmospheric reentry using a winged unmanned space vehicle. Proceedings of the 18th AIAA/3AF International Space Planes and Hypersonic Systems and Technologies Conference, Sept. 24-28, Tours, France.

DOI: $10.2514 / 6.2012-5857$

Patre, P. and S.M. Joshi, 2011. Accommodating sensor bias in MRAC for state tracking. Proceedings of the AIAA Guidance, Navigation and Control Conference, Aug. 8-11, American Inst. of Aeronautics and Astronautics, USA. DOI: 10.2514/6.2011-6605

Pelecudi, C., 1967. The Basics of mechanism analysis. Publishing house: Academy of the People's Republic of Romania.

Perumaal, S. and N. Jawahar, 2013. Automated trajectory planner of industrial robot for pick-andplace task. IJARS. DOI: 10.5772/53940

Petrescu, F. and R. Petrescu, 1995a. Contributions to optimization of the polynomial motion laws of the stick from the internal combustion engine distribution mechanism. Bucharest.

Petrescu, F. and R. Petrescu, 1995b. Contributions to the synthesis of internal combustion engine distribution mechanisms. Bucharest.

Petrescu, F. and R. Petrescu, 1997a. Dynamics of cam mechanisms (exemplified on the classic distribution mechanism). Bucharest.

Petrescu, F. and R. Petrescu, 1997b. Contributions to the synthesis of the distribution mechanisms of internal combustion engines with Cartesian coordinate method. Bucharest.

Petrescu, F. and R. Petrescu, 1997c. Contributions to maximizing polynomial laws for the active stroke of the distribution mechanism from internal combustion engines. Bucharest.

Petrescu, F. and R. Petrescu, 2000a. Synthesis of distribution mechanisms by the rectangular (cartesian) coordinate method. University of Craiova, Craiova. 
Petrescu, F. and R. Petrescu, 2000b. The design (synthesis) of cams using the polar coordinate method (the triangle method). University of Craiova, Craiova.

Petrescu, F. and R. Petrescu, 2002a. Motion laws for cams. Proceedings of the 7th National Symposium with International Participation Computer Assisted Design, (PAC' 02), Braşov, pp: 321-326.

Petrescu, F. and R. Petrescu, 2002b. Camshaft dynamics elements. Proceedings of the 7th National Symposium with International Participation Computer Assisted Design, (PAC' 02), Braşov, pp: 327-332.

Petrescu, F. and R. Petrescu, 2003. Some elements regarding the improvement of the engine design. Proceedings of the 8th National Symposium, Descriptive Geometry, Technical Graphics and Design, (GTD’ 03), Braşov, pp: 353-358.

Petrescu, F. and R. Petrescu, 2005a. The cam design for a better efficiency. Proceedings of the International Conference on Engineering Graphics and Design, (EGD' 05), Bucharest, pp: 245-248.

Petrescu, F. and R. Petrescu, 2005b. Contributions at the dynamics of cams. Proceedings of the 9th IFToMM International Symposium on Theory of Machines and Mechanisms, (TMM' 05), Bucharest, Romania, pp: 123-128.

Petrescu, F. and R. Petrescu, 2005c. Determining the dynamic efficiency of cams. Proceedings of the 9th IFToMM International Symposium on Theory of Machines and Mechanisms, (TMM' 05), Bucharest, Romania, pp: 129-134.

Petrescu, F. and R. Petrescu, 2005d. An original internal combustion engine. Proceedings of the 9th IFToMM International Symposium on Theory of Machines and Mechanisms, (TMM' 05), Bucharest, Romania, pp: 135-140.

Petrescu, F. and R. Petrescu, 2005e. Determining the mechanical efficiency of Otto engine's mechanism. Proceedings of the 9th IFToMM International Symposium on Theory of Machines and Mechanisms, (TMM' 05), Bucharest, Romania, pp: 141-146.

Petrescu, F. and V. Petrescu, 2014a. Balancing otto engines. Int. Rev. Mech. Eng., 8: 473-480.

Petrescu, F. and R. Petrescu, 2014b. Determination of the yield of internal combustion thermal engines. Int. Rev. Mech. Eng., 8: 62-67.

Petrescu, F. and R. Petrescu, 2014c. Forces of internal combustion heat engines. Int. Rev. Modell. Simulat., 7: 206-212.

Petrescu, F.I. and R.V. Petrescu, 2013. Cinematics of the 3R Dyad. Engevista, 15: 118-124.

Petrescu, F.I.T. and R.V. Petrescu, 2012a. The Aviation History. Publisher: Books On Demand, ISBN-13: 978-3848230778.
Petrescu, F.I. and R.V. Petrescu, 2012b. MecatronicaSisteme Seriale si Paralele. Create Space Publisher, USA, ISBN-10: 978-1-4750-6613-5, pp: 128.

Petrescu, F.I. and R.V. Petrescu, 2011. Mechanical Systems, Serial and Parallel-Course (in Romanian). LULU Publisher, London, UK, ISBN-10: 978-1-4466-0039-9, pp: 124.

Petrescu, F.I. and R.V. Petrescu, 2016a. Parallel moving mechanical systems kinematics, ENGEVISTA, 18: 455-491.

Petrescu, F.I. and R.V. Petrescu, 2016b. Direct and inverse kinematics to the Anthropomorphic Robots, ENGEVISTA, 18: 109-124.

Petrescu, F. and R. Petrescu, 2016c. An otto engine dynamic model. IJM\&P, 7: 038-048.

Petrescu, F.I. and R.V. Petrescu, 2016d. Otto motor dynamics, GEINTEC, 6: 3392-3406.

Petrescu, F.I. and R.V. Petrescu, 2016e. Dynamic cinematic to a structure 2R. GEINTEC, 6: 3143-3154.

Petrescu, F.I., B. Grecu, A. Comanescu and R.V. Petrescu, 2009. Some mechanical design elements. Proceeding of the International Conference on Computational Mechanics and Virtual Engineering, (MEC' 09), Braşov, pp: 520-525.

Petrescu, R.V., R. Aversa, A. Apicella, M.M. Mirsayar and F.I.T. Petrescu, 2016a. About the gear efficiency to a simple planetary train. Am. J. Applied Sci., 13: 1428-1436. DOI: 10.3844/ajassp.2016.1428.1436

Petrescu, R.V., R. Aversa, A. Apicella, S. Li and G. Chen et al., 2016b. Something about electron dimension. Am. J. Applied Sci., 13: 1272-1276. DOI: 10.3844/ajassp.2016.1272.1276

Petrescu, F.I.T., A. Apicella, R. Aversa, R.V. Petrescu and J.K. Calautit et al., 2016c. Something about the mechanical moment of inertia. Am. J. Applied Sci., 13: $1085-1090$. DOI: 10.3844/ajassp.2016.1085.1090

Petrescu, R.V., R. Aversa, A. Apicella, F. Berto and S. Li et al., 2016d. Ecosphere protection through green energy. Am. J. Applied Sci., 13: 1027-1032. DOI: 10.3844/ajassp.2016.1027.1032

Petrescu, F.I.T., A. Apicella, R.V. Petrescu, S.P. Kozaitis and R.B. Bucinell et al., 2016e. Environmental protection through nuclear energy. Am. J. Applied Sci., 13: 941-946. DOI: 10.3844/ajassp.2016.941.946

Petrescu, F.I.T. and J.K. Calautit, 2016a. About nano fusion and dynamic fusion. Am. J. Applied Sci., 13: 261-266. DOI: 10.3844/ajassp.2016.261.266

Petrescu, F.I.T. and J.K. Calautit, 2016b. About the light dimensions. Am. J. Applied Sci., 13: 321-325. DOI: 10.3844/ajassp.2016.321.325

Petrescu, R.V., R. Aversa, B. Akash, R. Bucinell and J. Corchado et al., 2017a. Modern propulsions for aerospace-a review. J. Aircraft Spacecraft Technol., 1: 1-8. DOI: 10.3844 /jastsp.2017.1.8 
Petrescu, R.V., R. Aversa, B. Akash, R. Bucinell and J. Corchado et al., 2017b. Modern propulsions for aerospace-part II. J. Aircraft Spacecraft Technol., 1: 9-17. DOI: $10.3844 /$ jastsp.2017.9.17

Petrescu, R.V., R. Aversa, B. Akash, R. Bucinell and J. Corchado et al., 2017c. History of aviation-a short review. J. Aircraft Spacecraft Technol., 1: 30-49. DOI: 10.3844 jastsp.2017.30.49

Petrescu, R.V., R. Aversa, B. Akash, R. Bucinell and J. Corchado et al., 2017d. Lockheed martin-a short review. J. Aircraft Spacecraft Technol., 1: 50-68. DOI: 10.3844 /jastsp.2017.50.68

Petrescu, R.V., R. Aversa, B. Akash, J. Corchado and F. Berto et al., 2017e. Our universe. J. Aircraft Spacecraft Technol., 1: 69-79. DOI: 10.3844/jastsp.2017.69.79

Petrescu, R.V., R. Aversa, B. Akash, J. Corchado and F. Berto et al., 2017f. What is a UFO? J. Aircraft Spacecraft Technol., 1: 80-90.

DOI: 10.3844 jastsp.2017.80.90

Petrescu, R.V., R. Aversa, B. Akash, J. Corchado and F. Berto et al., 2017g. About bell helicopter FCX-001 concept aircraft-a short review. J. Aircraft Spacecraft Technol., 1: 91-96. DOI: 10.3844/jastsp.2017.91.96

Petrescu, R.V., R. Aversa, B. Akash, J. Corchado and F. Berto et al., 2017h. Home at airbus. J. Aircraft Spacecraft Technol., 1: 97-118. DOI: $10.3844 /$ jastsp.2017.97.118

Petrescu, R.V., R. Aversa, B. Akash, J. Corchado and F. Berto et al., 2017i. Airlander. J. Aircraft Spacecraft Technol., 1: 119-148. DOI: $10.3844 /$ jastsp.2017.119.148

Petrescu, R.V., R. Aversa, B. Akash, J. Corchado and F. Berto et al., 2017j. When boeing is dreaming-a review. J. Aircraft Spacecraft Technol., 1: 149-161. DOI: 10.3844 /jastsp.2017.149.161

Petrescu, R.V., R. Aversa, B. Akash, J. Corchado and F. Berto et al., 2017k. About Northrop Grumman. J. Aircraft Spacecraft Technol., 1: 162-185. DOI: $10.3844 /$ jastsp.2017.162.185

Petrescu, R.V., R. Aversa, B. Akash, J. Corchado and F. Berto et al., 20171. Some special aircraft. J. Aircraft Spacecraft Technol., 1: 186-203. DOI: $10.3844 /$ jastsp.2017.186.203

Petrescu, R.V., R. Aversa, B. Akash, J. Corchado and F. Berto et al., 2017m. About helicopters. J. Aircraft Spacecraft Technol., 1: 204-223. DOI: 10.3844/jastsp.2017.204.223

Petrescu, R.V., R. Aversa, B. Akash, F. Berto and A. Apicella et al., 2017n. The modern flight. J. Aircraft Spacecraft Technol., 1: 224-233. DOI: $10.3844 /$ jastsp.2017.224.233

Petrescu, R.V., R. Aversa, B. Akash, F. Berto and A. Apicella et al., 2017o. Sustainable energy for aerospace vessels. J. Aircraft Spacecraft Technol., 1: 234-240. DOI: 10.3844/jastsp.2017.234.240
Petrescu, R.V., R. Aversa, B. Akash, F. Berto and A. Apicella et al., 2017p. Unmanned helicopters. J. Aircraft Spacecraft Technol., 1: 241-248. DOI: $10.3844 /$ jastsp.2017.241.248

Petrescu, R.V., R. Aversa, B. Akash, F. Berto and A. Apicella et al., 2017q. Project HARP. J. Aircraft Spacecraft Technol., 1: 249-257. DOI: $10.3844 /$ jastsp.2017.249.257

Petrescu, R.V., R. Aversa, B. Akash, F. Berto and A. Apicella et al., 2017r. Presentation of Romanian engineers who contributed to the development of global aeronautics-part I. J. Aircraft Spacecraft Technol., 1: 258-271. DOI: 10.3844 /jastsp.2017.258.271

Petrescu, R.V., R. Aversa, B. Akash, F. Berto and A. Apicella et al., 2017s. A first-class ticket to the planet mars, please. J. Aircraft Spacecraft Technol., 1: 272-281. DOI: 10.3844/jastsp.2017.272.281

Petrescu, R.V., R. Aversa, B. Akash, F. Berto and A. Apicella et al., 2017t. Forces of a 3R robot. J. Mechatron. Robot., 1: 1-14. DOI: $10.3844 /$ jmrsp.2017.1.14

Petrescu, R.V., R. Aversa, B. Akash, F. Berto and A. Apicella et al., 2017u. Direct geometry and cinematic to the MP-3R systems. J. Mechatron. Robot., 1: 15-23. DOI: 10.3844/jmrsp.2017.15.23

Petrescu, R.V., R. Aversa, B. Akash, F. Berto and A. Apicella et al., 2017v. Dynamic elements at MP3R. J. Mechatron. Robot., 1: 24-37. DOI: $10.3844 /$ jmrsp.2017.24.37

Petrescu, R.V., R. Aversa, B. Akash, F. Berto and A. Apicella et al., 2017w. Geometry and direct kinematics to MP3R with $4 \times 4$ operators. J. Mechatron. Robot., 1: 38-46. DOI: 10.3844 jmrsp.2017.38.46

Petrescu, R.V., R. Aversa, A. Apicella, M.M. Mirsayar and S. Kozaitis et al., 2017x. Current stage in the field of mechanisms with gears and rods. J. Mechatron. Robot., 1: 47-57. DOI: 10.3844/jmrsp.2017.47.57

Petrescu, R.V., R. Aversa, A. Apicella, M.M. Mirsayar and S. Kozaitis et al., 2017y. Geometry and inverse kinematic at the MP3R mobile systems. J. Mechatron. Robot., 1: 58-65. DOI: $10.3844 /$ jmrsp.2017.58.65

Petrescu, R.V., R. Aversa, A. Apicella, M.M. Mirsayar and S. Kozaitis et al., 2017z. Synthesis of optimal trajectories with functions control at the level of the kinematic drive couplings. J. Mechatron. Robot., 1: 66-74. DOI: 10.3844/jmrsp.2017.66.74

Petrescu, R.V., R. Aversa, A. Apicella, M.M. Mirsayar and S. Kozaitis et al., 2017aa. The inverse kinematics of the plane system 2-3 in a mechatronic MP2R system, by a trigonometric method. J. Mechatron. Robot., 1: 75-87. DOI: $10.3844 / j m r s p .2017 .75 .87$ 
Petrescu, R.V., R. Aversa, A. Apicella, M.M. Mirsayar and S. Kozaitis et al., 2017ab. Serial, anthropomorphic, spatial, mechatronic systems can be studied more simply in a plan. J. Mechatron. Robot., 1: 88-97. DOI: 10.3844/jmrsp.2017.88.97

Petrescu, R.V., R. Aversa, A. Apicella, M.M. Mirsayar and S. Kozaitis et al., 2017ac. Analysis and synthesis of mechanisms with bars and gears used in robots and manipulators. J. Mechatron. Robot., 1: 98-108. DOI: 10.3844/jmrsp.2017.98.108

Petrescu, R.V., R. Aversa, A. Apicella, M.M. Mirsayar and S. Kozaitis et al., 2017ad. Speeds and accelerations in direct kinematics to the MP3R systems. J. Mechatron. Robot., 1: 109-117. DOI: $10.3844 /$ jmrsp.2017.109.117

Petrescu, R.V., R. Aversa, A. Apicella, M.M. Mirsayar and S. Kozaitis et al., 2017ae. Geometry and determining the positions of a plan transporter manipulator. J. Mechatron. Robot., 1: 118-126 DOI: $10.3844 /$ jmrsp.2017.118.126

Petrescu, R.V., R. Aversa, T. Abu-Lebdeh, A. Apicella and F.I.T. Petrescu, 2018. Kinematics of a mechanism with a triad. Am. J. Eng. Applied Sci., 11: 297-308. DOI: 10.3844/ajeassp.2018.297.308

Reddy, P., K.V. Shihabudheen and J. Jacob, 2012. Precise non linear modeling of flexible link flexible joint manipulator. IReMoS, 5: 1368-1374.

Sevil, H.E and A. Dogan, 2015. Fault diagnosis in air data sensors for receiver aircraft in aerial refueling. J. Guidance Control Dynam., 38: 1959-1975. DOI: $10.2514 / 1 . G 000527$

Sherson, J.F., H. Krauter, RK. Olsson, B. Julsgaard and K. Hammerer et al., 2006. Quantum teleportation between light and matter. Nature, 443: 557-560. DOI: 10.1038 /nature05136
Sun, J.Z. and S.M. Joshi, 2009. An indirect adaptive control scheme in the presence of actuator and sensor failures. Proceedings of the AIAA Guidance, Navigation and Control Conference, Aug. 10-13, Chicago, Illinois. DOI: 10.2514/6.2009-5740

Tabaković, S., M. Zeljković, R. Gatalo and A. Živković, 2013. Program suite for conceptual designing of parallel mechanism-based robots and machine tools. Int. J. Adv. Robot Syst.

DOI: $10.5772 / 56633$

Tang, X., D. Sun and Z. Shao, 2013. The structure and dimensional design of a reconfigurable PKM. IJARS. DOI: $10.5772 / 54696$

Tong, G., J. Gu and W. Xie, 2013. Virtual entity-based rapid prototype for design and simulation of humanoid robots. Int. J. Adv. Robot. Syst. DOI: $10.5772 / 55936$

Venkataraman, G., 1992. Chandrasekhar and his Limit. 1st Edn., Universities Press, ISBN-10: 817371035X, pp: 89.

Wang, K., M. Luo, T. Mei, J. Zhao and Y. Cao, 2013. Dynamics analysis of a three-DOF planar serialparallel mechanism for active dynamic balancing with respect to a given trajectory. Int. J. Adv. Robotic Syst. DOI: 10.5772/54201

Williams, D.R., 1995. Saturnian satellite fact sheet. NASA.

Wen, S., J. Zhu, X. Li, A. Rad and X. Chen, 2012. Endpoint contact force control with quantitative feedback theory for mobile robots. IJARS.

DOI: $10.5772 / 53742$ 